\title{
THE STUDENTS’ SPEAKING ABILITY IN EXPRESSING GRATITUDE AND APPRECIATION
}

\author{
Rahmat Huda \\ Dosen Bahasa Inggris Fakultas Keguruan dan Ilmu pendidikan \\ Universitas Muhammadiyah Tapanuli Selatan Padangsidimpuan
}

\begin{abstract}
In Indonesia, English as foreign language or second language use by most of people and English is a second language that should be mastered by language learners. In teaching English, four-language skills such as; listening, speaking, reading, and writing should be taught integrated to the language learners. Speaking is primary of language skill. The good teacher is able to find techniques in teaching and learning process. One of technique which is used in teaching speaking ability is expressing gratitude and appreciation This study was descriptive research. The target population of this study was all of the first grade of SMK Negeri 1 Padangsidimpuan. The number of population was 400 students. The researcher took 40 students as sample. To collect the data, the researcher used speaking test. The speaking test was used to measure the students' speaking ability and their score was analyzed by using descriptive statistic. The result of analysis indicated that the speaking skill of students was 44,45 with standard deviation (SD) was 6,32. The highest students' score on speaking test was 76 and the lowest score was 23. It means that students' speaking ability at the first grade of SMK Negeri 1 Padangsidimpuan was at level 2.

Keywords; appreciation, gratitude, speaking abilityINTRODUCTION
\end{abstract}

Language is system of sound symbol used by humans to communicate. Finnochiaro and Brumfit in Richard and Rodger (1995:65) said that language means as communication. It has an important rule for human life, by using language the people will express their ideas, emotion, and desires, and it is used as a medium in interacts between one another to fulfill their daily need.

Language can be applied in many aspects, such as: education, society, politics, economics, and culture. One of the ways in communication is through speaking. It is very important to master speaking well. To master speaking ability, students must be trained to use English in communication orally. The frequency in using the language will determine the success in speaking ability. Without implementing the experience of learning the language in the real life, it is difficult for the students to master speaking ability. Hence, speaking competence can be accomplished by practicing it orally. In many countries in the world, English have set the language as one of the compulsory subject studied at school.

In Indonesia, English is taught at SMP (Junior High School), SMA (Senior High School), SMK (Vocational High School), in University, many courses and it has also been 
taught at SD (Elementary School). Knowing that English is quite significant for Indonesia in the future. The government always makes efforts to improve the quality of English teaching, escpecially in speaking.

Speaking is one of four language skill, which is basic function of language as communication instrument. It is important for the students to practice their capability and their understanding, how to send idea, and how to spell word well. In this case, the students' motivation and interest are very needed to make the process of their understanding more easily.

In teaching speaking, most of teachers wish their students could speak English, but it is not as easy as they hope. It needs various ways in teaching the target. In this case, one of the ways of speaking is expressing gratitude and appreciation in conversation form.

To make the students have strong interest in teaching and learning process, especially in learning speaking, the teacher should take the best approach, method, and strategies. Then, the teacher can use gratitude and appreciation in teaching of English language; both are used to help the students for speaking to make interaction between the students with students and the others.

According to the writer's experienced in field of education practice (PKL), there were many students who are unable to express their feeling and thought. They were shy, fear and worried to make mistake. The writer wants to lose the negative image of students about

ISSN 2541-3775 speaking, make them brave and sure with their ability in speaking. The writer hopes that gratitude and appreciation can motivate the students to speak English to communicate their need, especially in the classroom and in their daily need in general. It is interested to investigate the students' speaking ability, especially in expressing gratitude and appreciation.

Based on the previous description, the writer decides to investigate this phenomenon entitled: “Students' Speaking Ability in Expressing Gratitude and Appreciation at the First Grade of SMK Negeri 1 Padangsidimpuan.”

\section{RESEARCH METHOD}

\section{Method of the research}

In conducting the research, the writer used a quantitative method, because in collecting the data needed and used the numeral. This method has an intention to accumulate the basic data, as is stated by Suharsimi Arikunto:

"Sebaiknya dengan penelitian
kuantitatif, sesuai dengan banyak
namanya dituntut menggunakan angka,
mulai dari pengumpulan data hingga
penafsirannya terhadap data tersebut,
serta penampilan dari hasilnya
memungkinkan untuk diwakilkan.”
Suharsimi Arikunto (2008:12-13)
As contrary with the quantitative
h, suited with it name called, some claim
g a numeral, begin from collecting until


interpretation of the data, along with the presentation of that result is enable to viced.

\section{Type of the research}

The type of this study was descriptive research, in which tried to analyze the students' ability in expressing gratitude and appreciation, which are produced by students related to the oral production.

In this research, the writer prepared or sets up communication strategies toward speaking fluency. For the students who were examined to answer speaking that would be tested.

\section{Population and Sample}

\section{a. Population}

Suharsimi Arikunto (2008) states:

"Population is the number of people which have the same characteristic, or a set of collection, all elements processing one or more attributes of interest.”

Meanwhile, Arifin (2003:6) states that a population is a number objects with a certain characteristic that are aimed at a field of investigation.

Based on the definition above, the writer inferred that population is all of the subjects of study which is examined. The population of this research is all the first grade of SMK Negeri 1 Padangsidimpuan. The total numbers of the students are 400 students. They are divided into fourteen classes; they are $1 A D M$ 1, $1 A D M$ 2, 1 ADM 3, 1 ADM 4, 1 AK 1, 1 AK 2, 1 AK 3, 1 AK
4, 1 TKJ 1, 1 TKJ 2, 1 TN 1, 1 TN 2, 1 Keperawatan 1, and 1 Keperawatan 2.

Explanation:

ADM : Admnistrasi

AK : Akuntansi

TKJ : Teknik Komputer dan Jaringan

TN : Tata Niaga

Source: Tata Usaha SMK Negeri 1 Padangsidimpuan T.A. 2013-2014.

\section{b. Sample}

Suharsimi Arikunto (2008) states that sample is part of representative population examined or investigated. If the number of population was more than one hundred, the writer takes $10-15 \%, 20-25 \%$. But, if the numbers of population less than a hundred, the writer takes the whole population as sample.

The writer selected the sample from TKJ Program, which consists of 40 students. The number of the population of this research was 400 students, but the writer took $10 \%$ as the sample. Thus, the counting of $10 \%$ from 400 is taken 40 students as the sample of the research. The technique of taking sample was cluster sampling.

Sugiyono (2003:78) states that: “cluster sampling yaitu cara pengambilan sampel yang berdsarkan kepada cluster-cluster tertentu.”

The writer took the sample of research only one class; it was 1 TKJ 1.

Table 3.2 Sample of research

\begin{tabular}{|c|c|c|}
\hline Class & Sex & Total \\
\hline 1 TKJ & Male & 23 \\
\cline { 2 - 3 } 1 & Female & 17 \\
\hline
\end{tabular}

Vol.3 No.1 Januari - Juni 2018/9 


\begin{tabular}{|l|l|l|}
\hline & Total Students & $\mathbf{4 0}$ \\
\hline
\end{tabular}

\section{Instrument of Collecting Data}

Instrument takes an important role for collecting of data. The accuracy of the result is very determined on how accurate the use of instrument. Relating to research problem, the writer used oral test (conversation exchange) in collecting data to the students' knowledge or understanding to express gratitude and appreciation.

The writer informed the kind of test that used in this research is speaking test as an instrument. The aim was to measure the skill, knowledge, and ability. This test is suitable to focus on a certain aspect of spoken language.

\section{Technique of Collecting Data}

Data collection is one of the important steps in conducting of research. The data is collected by taking of speaking achievement test. In order to get data, the writer administrated the way of collecting data as follow: (1) The writer prepared statement in situation form which focused in gratitude and appreciation, (2) The students were given time to study the situation and changed the situations into conversation form, (3) Then, they practiced the situations into conversation with their partner.

The writer will score the language Factor such as pronunciation or accent, grammar, vocabulary, fluency, and comprehension. The scoring will be done when applying of the strategy is in progress, so the writer is easy to observe.

\section{Technique of Analyzing Data}

The data that has been collected will be analyzed in statistic method, because the research is done base on the quantitative research, so the analyzing of the data will use numeral. In this research, the writer will do evaluation by scoring to know the students' speaking ability in expressing gratitude and appreciation. To take the value, the writer used of mean formula:

$$
\overline{\mathrm{X}}=\frac{\sum \mathrm{X}}{\mathrm{N}}
$$

Where:

$$
\begin{aligned}
& \bar{X}=\text { the mean } \\
& \sum=\text { the sum of } \\
& \mathrm{X}=\text { each of values in the distribution } \\
& \mathrm{N}=\text { the number of cases }
\end{aligned}
$$

(Introduction to Research in Education, 1979:103)

The writer used the formula, because the script was content of one variable. Mean is the average score and by knowing the mean. The writer wanted to know the students' speaking ability in expressing gratitude and appreciation. The formula above is also supported the following scale:

\section{Table 3.3}

\section{Conversational English Proficiency} Weighting Table

Vol.3 No.1 Januari - Juni 2018/10 


\begin{tabular}{|l|l|l|l|l|l|l|l|l|l|}
\hline No & $\begin{array}{c}\text { Proficiency } \\
\text { Descriptions }\end{array}$ & $\rightarrow$ & $\mathbf{1}$ & $\mathbf{2}$ & $\mathbf{3}$ & $\mathbf{4}$ & $\mathbf{5}$ & $\mathbf{6}$ & Total \\
\hline 1 & Accent & 0 & 1 & 2 & 2 & 3 & 4 & \\
\hline 2 & Grammar & 6 & 12 & 18 & 24 & 30 & 36 & \\
\hline 3 & Vocabulary & 4 & 8 & 12 & 16 & 20 & 24 & \\
\hline 4 & Fluency & 2 & 4 & 6 & 8 & 10 & 12 & \\
\hline 5 & Comprehension & 4 & 8 & 12 & 15 & 19 & 23 & \\
\hline
\end{tabular}

The third way is scoring, here the writer score the value of language factor (Accent, Grammar, Vocabulary, Fluency, and Comprehension). The reference taken from Jack C. Ricards \& Willy A. Renandya (2005:224). The writer used the following Conversational English Proficiency Conversion to know the students ability in which level they were.

Table 3.4 Conversational English Proficiency Conversion Table

\begin{tabular}{|c|c|}
\hline Total Score & Level \\
\hline $16-25$ & $0+$ \\
$26-32$ & 1 \\
$33-42$ & $1+$ \\
\hline $43-52$ & 2 \\
$53-62$ & $2+$ \\
$63-72$ & 3 \\
\hline $73-82$ & $3+$ \\
$83-92$ & 4 \\
$93-99$ & $4+$ \\
\hline
\end{tabular}

According to Higgs and Clifford (1982) in Jack Ricard and Willy A. Renandya's book. (2005:221-222), it explains that in Conversational English Proficiency Ratings there are five levels.

Based on Jack C. Richards and Willy A. Renandya books' (2002:222-223), in English conversation there are five factors and descriptors of conversational performance that used by the writer in the oral English of students test, they are accent, vocabulary, grammar, fluency and comprehension.

\section{FINDINGS AND DISCUSSIONS}

\section{Data Description}

In this part, the research tries to present the result of the research, that concern students' speaking ability in expressing gratitude and appreciation at the first grade of SMK Negeri 1 Padangsidimpuan in 2013-2014 Academic Year.

Students' speaking ability in expressing gratitude and appreciation was measured by means of students' conversation. The oral test was done by all of the sample of the study. The results of the responses of the subjects did conversation was clarified by the scores.

The writer got the score from students' performance in speaking practice. It scoring based on the table 3.5 of language factors and descriptors of conversational performance and converted of the students' scores to the conversational English proficiency conversion.

In this case, the results of the analysis test were 40 students who did the conversation 
test, the highest score was 76. Whereas, the lowest score was 23, the mean score of their speaking ability to do the conversation was 43,1. Based on the table 3.4 of conversational English proficiency conversion table in chapter III, it shows that 44,45 included at level 2.

\section{Discussion}

In this case, the writer presented about the speaking ability and the achievement level of speaking ability test at the first grade of SMK Negeri 1 Padangsidimpuan, which have been stated on the formulation of the problem in this study. To answer the researcher's question and to achieve the objective of the study, the research of the analysis was presented in the previous chapter.

Based on the results of the analysis were presented in the previous chapter, the writer concluded that the achievement level of students ability in expressing gratitude and appreciation in speaking was 44,45 . Looking at this score and then conversed with the criteria of the level at the weighting table of the comprehensive description of the FSI procedure and the conversion table of weighting table of the comprehensive description of the FSI procedure.

It can be seen the value of mean score of the respondent is 44,45 . Based on the table 3.5 of Conversational English Proficiency Conversion in Jack C. Richards \& Willy A. Renandya (2005:223), the score more than 43-45 means in the level 2.
From the total respondents are 40 students, there were two (2) students who got level 3+, four (4) students at level 3, five (5) students at level 2+, twelve (12) students at level 2 , ten (10) students at level $1+$, three (3) students at level 1, and four (4) students at $0+$. To know the definitions of each level, the writer prepared to make it easy to comprehend what did of each level means.

The difficulties of the students' speaking ability are: 1) Clustering, 2) Redundancy, 3) Reduced forms, 4) Performance variables, 5) Colloquial language, 6) Rate of delivery, 7) Interaction, and 8) Stress, rhythm, and intonation.

The most effect of students' speaking ability was in their internal factor, especially in their talent. While from external factor, is in their environment. Most of students less experience and practice, because there were no people and special area to practice English itself.

\section{Conclusion}

Based on the discussion on the previous chapter, this study can be concluded that the students of SMK Negeri 1 Padangsidimpuan were average in their English speaking ability. This is conducted from the results of the test that the average of English speaking ability was 44,45 with the standard deviation (SD) was 6,32. It was also found out the highest students' score on the English speaking test through conversation about gratitude and appreciation in speaking ability was 76 , and the lowest score 
was 23. It means that English speaking ability for the first grade, especially in TKJ program were average (based on FSI procedure).

The last, the writer wants to say that from the spoken data analyzed some of them made some errors covered with the pronunciation and structure.

\section{References}

Arifin, 2003. Statistik Dasar. Singaraja: IKIP Singaraja.

Arikunto, Suharsimi. 2008. Prosedur Penelitian Suatu Pendekatan Praktik. Jakarta: PT. Bina Aksara.

Ary, Donald, 1979. Introduction to Research in Education. New York: Northern Illinois University.

Breen and Candlin, 1989. The Essentials of $a$ Communicative Curriculum in Language Teaching. Washington D.C.: Georgetown University Press.

Brown, H.D, 1987. Principles of Language Learning and Teaching. New York: Cambridge University Press.

Carol J, Orwig. 1999. Speaking Skill. Internet Tessol. http://w.w.w. Sil. org.

Djiwandono, M. Soenardi, 2006. Tes Bahasa Dalam Pengajaran. Bandung: Penerbit ITB.

Finnochiaro, and Brumfit, 1987. Functional National Approach from Theory to Practice. Oxford University Press.

Fraser, Bruce, 2000. Acquiring Social Competence in a Social Language. Massachusetts: New Burry House Publishers.

Hariyono, Rudy, 2006. Serious English for Serious Student. Surabaya: Gitamedia Press.
Harmer, Jeremy, 2005. Longman Dictionary of Contemporary English. United States of America: Cambridge University Press. , 2001. The Practice of English Language Teaching. London: Longman.

Haryanto, Han, 2004. Pend ! Bahasa Inggris. Jakarta: Univers erbuka.

Heaton, JB, 2005. Writing English Language Test. Singapore: Longman Group Ltd.

Longman Dictionary of Contemporary English. United States of America: Longman Group Ltd.

Hornby, A.S, 1995. Oxford Advanced Learner's Dictionary of Current English 5th Edition. London: Oxford University Press.

2005. Oxford Advanced Learner's Dictionary of Current English 7th Edition. London: Oxford University Press.

Junaidi, 2004, Students' Speaking Ability in the Second Year Students of MA Mu'allimat NW Pancor in the school year 2003/2004. STKIP Hamzanwadi Selong. Unpublished S-1 Thesis.

Julia, M. Dobson, 2007. Effective Technique of English Conversation Group. Boston: English Language Programmer Dentition.

Mardini, Siti Era, 1995. Module Teaching Speaking, Jakarta: Balai Pustaka.

Muhammad, A.M. 2004, "Communicative Interaction: The Key Teaching Language”. Majalah Ilmiah Kopertis Wilayah VIII: Denpasar-Bali.

Munir, Ahmad. 2005. Communication Strategies Toward Students' Speaking Ability.

Vol.3 No.1 Januari - Juni 2018/13 
Selong STKIP Hamzanwdi. Thesis S-1. Unpublished.

Munjayanah, Anik, 2004. The Implementation of Communicative Language Teaching Speaking at LIA Surakarta: An Ethnography. Surakarta: UMS.

Nunan, David, 2005. Practical English Language Teaching, McGraw Hill: Canada.

Nurhadi, 2007, Kapita Selekta Bahasa dan Sastra. Malang: IKIP Malang.

Nurkancana, Wayan and PPN, Sumartono, 2006. Evaluasi Pendidikan. Surabaya: Usaha Nasional.

Paiman, 2007. Psikologi Perkembangan. Jakarta: Universitas Terbuka

Ricard, Jack C., \& Renandya, Willy A, 2002. Methodology in Language Teaching United States of America: Cambridge University Press.

Richards, J.C. Rodgers. 1986. Approach and Method in Language Teaching. New York: Cambridge University Press.

Sadjono, 1987. Anatologi Pembelajaran Bahasa Asing Khususnya Bahasa Inggris, PPLPTK Press.

Sharna, Robina.___. Macro Skill of Speaking. Intrenet Tessol, http://w.w.w. Ehow. Com.

Sulastri, Eka. 2009.” The Influence of Daily English Speaking on the Students' Ability in Speaking”, script publish, UNNES.

Suryabrata, Sumadi, 2002. Psikologi Pendidikan. Jakarta: PT. Raja Grapindo Persada.

Tarigan, Henri Guntur, 2005. Berbicara Sebagai Keterampilan Berbahasa. Bandung: Angkasa. http://www.englishedu.org/30/09/2013/englishresearch/senin/30/09/2013/14:21

http://idtesis.com/teknik-teknik-dalammenentukan-pengambilan-sampelpenelitian-skripsi. Accessed on Friday, 8 Nov 2013 at 07:45 wib.

http://digilib.unimus.ac.id/files/disk1/112/jtptuni mus-gdl-devifebria-5590-4-babiii-f.pdf. Accessed on Firdayt, 8 Nov 2013 at 07:50 wib. 